\title{
Analysis of The Profitability Ratio Effect, Market Value Ratio, and Coal Prices to Stock Prices of Coal Companies
}

\author{
Abdul Sani Sihotang, Anita Munir \\ TANRI ABENG UNIVERSITY \\ sanisihotang14@gmail.com, munir.anita@tau.ac.id \\ Received: February $5^{\text {th }} 2021$ \\ Approved: April 2nd 2021
}

\begin{abstract}
This study aims to examine the effect of profitability ratios (EPS and NPM), market value ratios (PBV), and reference coal prices (HBA) on stock prices in 2009 - 2019. This study is a quantitative descriptive approach with the company chosen by ADRO, ITMG, and PTBA. The method of analysis used descriptive analysis and multiple linear regression analysis. Hypothesis testing uses the t-test to test the coefficient partially, and the Goodness of Fit test uses R2 (Coefficient of Determination) to test simultaneously. All variables have been tested using the classical assumption test. The results showed that all variables passed the classical assumption test and were suitable for research data. The statistical t-test results show that the variable earning per share ratio (EPS) partially has a significant and positive effect on stock prices. The ratio variable of net profit margin (NPM) partially has a significant and negative effect on stock prices. The price to book value (PBV) ratio variable partially has a significant effect on stock prices, and the reference coal price (HBA) partially has a negative but not significant effect on stock prices. Simultaneously, the ratio of Earning per Share (EPS), Net Profit Margin (NPM), Price to Book Value (PBV), and Coal Price (HBA) has a significant effect on stock prices. This is explained by Sig F. $=0,000<$ Level of Significant $=0.05$, and the value of R2 (coefficient of determination) is $92.8 \%$, while other factors outside the model explain the remaining $7.2 \%$. This research can be used by companies and investors who will invest.
\end{abstract}

Keyword :

Earning per Share (EPS), Net Profit Margin (NPM), Price to Book Value (PBV), Reference Coal Price (HBA), and Price Stock. 


\section{Introduction}

Investment can be defined as an activity to place funds in one or more assets during a specific period with the hope of earning income and increasing investment value. Purchasing shares of a company through the capital market is an alternative form of investment widely used today. Shares are equity participation in a company. As evidence of such participation, a share certificate is issued to the shareholders so that someone who holds or owns shares in a specific company becomes the company's owner. The main objective of companies investing is a rate of return. According to Husnan (2011), investors' primary objective to invest in securities, among others, is to obtain the maximum rate of return through policies; for example, dividends at a specific risk will obtain certain returns at minimal risk.

The level of interest of an investor in investing in stocks is influenced by the value of shares in the capital market. According to Djazuli \& Fitri (2016), the high and low value of shares is reflected in company performance reflected in a company's financial performance. Anita Munir (2020), the mining compaies have the opportunity that the price will increase because it is an important sector in supporting the life of the country which gives a positive response to the company. Therefore, shareholders can consider continuing to invest in the long term.

Many variables can affect a company's stock price, both those that come from the external environment or those that come from the company's internal environment. Variables that come from internal companies such as financial ratios (profitability) or other financial ratios that can affect stock prices.

The stock price as a representation of company value can be determined by three factors: internal company factors, company external factors, and technical factors.

The company's internal factors in this study are the profitability ratio (EPS and NPM). Profitability is one of the variables that affect the capital structure. Profitability calculations can be represented by earnings per share (EPS) and net profit margin (NPM). According to Mamduh (2010), profitability is the company's ability to generate profits (profits) at a certain level of sales, assets, and share capital. The company's high profitability causes the company to use more funding from within the company because if the profitability is higher, the company can provide a more significant amount of retained earnings (Margaretha \& Karnida, 2016).

Internal and technical factors in this study are the market value ratio (PBV). In stock 
investment, the market value ratio can be represented by price to book value (PBV), which compares the company's book value and the market share price. Value (PBV) can provide information that the price of shares in the market is low or expensive, which can be seenfrom the PBV value, such as $<1$ describes the value of shares sold on the cheap market, whereas if $>1$ the price of shares in the market is high.

Meanwhile, the external factor of the company in this study is the price of coal. In the other commodity investment sector, it can be seen that the high index growth in the mining sector shows a great deal of investor interest in mining sector stocks, which are seen as a profitable investment option.

Mining companies were purposively selected because they are one of the pillars of economic activity in Indonesia, play an essential role as one of Indonesia's export commodities, and attract foreign investors to invest in Indonesia.

Table 1

Indonesia's Export Value According to Important Commodities ( Million US\$)

\begin{tabular}{|c|c|c|c|}
\hline Export Commodities & 2017 & 2018 & 2019 \\
\hline Coal & $17.877,0$ & $20.631,4$ & $18.886,3$ \\
\hline Copper Ore & $3.439,6$ & $4.186,7$ & $1.280,1$ \\
\hline Other Mining Results & $2.987,2$ & $4.467,9$ & $4.655,9$ \\
\hline
\end{tabular}

Source: Economic Indicators 2020, BPS

Apart from acting as an export commodity, coal companies can attract foreign investors to invest in Indonesia. Can be seen in the amount of foreign capital that enters Indonesia in the table below:

Table 2

Foreign Direct Investment (Million US \$) 2017 - 2019

\begin{tabular}{|c|c|c|c|}
\hline Sector & 2017 & 2018 & 2019 \\
\hline Mining & $4.375,9$ & $3.038,6$ & $2.256,3$ \\
\hline Percentage to amount & $13,57 \%$ & $10,37 \%$ & $8,00 \%$ \\
\hline Amount of PMA & $32.239,8$ & $29.307,9$ & $28.208,8$ \\
\hline
\end{tabular}

Source: Economic Indicators 2020, BPS

The flow of funds from foreign investors in Indonesia has made the mining industry develop rapidly over a long period. Because according to the Ministry of Energy and Mineral Resources (ESDM), Indonesia's coal reserves reach 37 billion tons. This amount is estimated to last up to 62 years if mining is carried out. 


\section{Literature Review}

Investment can be interpreted as an activity to invest either directly or indirectly with the hope that investors will get the amount of profit from the investment (Hamid in Ansor, 2010). Another investment definition states that investment is an activity of placing funds in one or more of an asset during a certain period in the hope of earning income or an increase in investment value (Jones in Ansor, 2010).

According to Husnan (2011), the share price is the present value of income that investors will receive and received by investors in the future. Meanwhile, according to Jogiyanto (2012), the share price is the price that occurs on the stock market at a specific time, and market players determine the share price. Keown et al. (2010) explained that the company's main objective is to maximize the value or stock price.

Natarsyah (2010) states that every stock investment has a strong foundation in the fundamental analysis, namely intrinsic value that can be determined by analyzing the current condition of the company and its prospects in the future.

The argument is clear that stock value represents company value, not only intrinsic value but also as important as the expectation of its ability to increase value in the future (Martono, 2010).

Fundamental analysis tries to predict future stock prices by (Husnan 2011):

a. Estimating the value of the fundamental factors that affect stock prices in the future.

b. Apply the relationship of these variables to obtain an estimate of the stock price

According to Husnan (2010) technical analysis attempts to estimate stock prices by observing stock price changes in the past. Sutrisno (2014) states that technical analysis is an investment approach by studying historical data from stock prices and relating it to the trading volume that occurs and the economic condition. The assumptions that apply in this analysis include:

a. Supply or demand itself is influenced by many factors, both rational and international.

b. Changes in stock prices tend to move according to specific trends.

c. This trend can change due to shifting of supply and demand

Earning per share (EPS) is the company's net income divided by the number of ordinary shares outstanding. If earnings per share are higher, then the company's prospects are better, while lower earnings per share mean less profitable, and negative earnings per share mean it is not good (Samsul, 2016). The number of EPS of a company 
can be seen from the company's financial statement information. However, not all companies include the number of EPS in their financial statements. Earning Per Share (EPS) shows the share of earnings for each share.

Alexandri (2010) Net Profit Margin (NPM) is a ratio used to show a company's ability to generate net profit after taxes. According to Husnan (2015), NPM is calculated from net profit after tax on sales. Net Profit Margin (NPM) aims to measure the return rate on net profits against net sales. Price to Book Value (PBV) is a ratio that measures the fair price of shares by comparing market share prices with book value per sheet (Fahmi, 2018). The lower the PBV <1, the stock is said to be cheap or undervalued, but the higher the PBV value > 1, the stock can be said to be expensive or overvalued, but low or high PBV can indicate the fundamental quality of the issuer, it is necessary to compare PBV with other issuers in the same industry (Hery, 2016). The PBV ratio describes the fundamental value and the appreciation of the investors against the stock price. The determination of reference coal prices (HBA) has been regulated in the Director- General of Mineral and Coal Regulation No. 515.K / 32 / DJB / 2011. HBA is significantly affected by macroeconomic conditions because it is a commodity for international trade. Reference Coal Price Value (HBA) is derived from the average of 4 coal price indexes commonly used. Reference Coal Price Value (HBA) is derived from an average of 4 (four) coal price indices commonly used. Namely the Indonesia Coal Index, Platts Index, New Castle Export Index, and New Castle Global Coal Index.

$$
\mathrm{HBA}=25 \% \mathrm{ICI}+25 \% \text { Platts }+25 \% \mathrm{NEX}+25 \% \mathrm{GC}
$$

$\mathrm{HBA}=$ Reference Coal Price

ICI = Indonesia Coal Index

$\mathrm{NEX}=$ New Castle Export Index

$\mathrm{GC}=$ New Castle Global

Coal Index

\section{Methodology}

The design of this research is a quantitative descriptive approach. Namely, critical observation and investigation to obtain accurate information on a particular problem and object in a particular community group area or location will be studied or describe or describe a situation as clearly as possible without any treatment of the object under study, namely the effect of profitability ratios (EPS and NPM), market value ratios (PBV), and reference coal prices (HBA) as predictors of stock prices. The type of research used is field 
research, in which researchers distribute questionnaires directly to the research location

This study's population is a go public mining company listed on the Indonesia Stock Exchange (IDX), which listed its shares from January 1, 2009, to December 31, 2019. The coal mining company that will be studied is PT. ADRO, PT. PTBA and PT. ITMG.

Sources of data in this study are by downloading coal mining company financial report data on the idx.co.id website and on the issuer's website: www.adaro.com (ADRO); www.ptba.co.id (PTBA); www.itmg.co.id (ITMG). Sources of reference coal price data can be seen on the website www.minerba.esdm.go.id. Share price data on the finance.yahoo.com website

Descriptive analysis in this study describes (describes) the mean, minimum, maximum, and standard deviation of each research variable.

Multiple linear regression analysis was used to analyze and test the hypothesis in this study, and the significance level used was $5 \%$. Hypothesis testing uses the t-test. The following is a multiple linear regression equation:

$$
\mathrm{SP}=\alpha+\beta_{1} \mathrm{EPS}+\beta_{2} \mathrm{NPM}+\beta_{3} \mathrm{PBV}+\beta_{4} \mathrm{HBA}+\mathrm{ei}
$$

$$
\begin{array}{ll}
\text { SP } & : \text { Stock Price } \\
\alpha & : \text { Constant } \\
\text { EPS } & : \text { Earning Per Share } \\
\text { NPM } & : \text { Net Profit Margin } \\
\text { PBV } & : \text { Price to Book Value } \\
\text { HBA } & : \text { Reference coal prices } \\
\text { ei } & : \text { Error Term }
\end{array}
$$

The classical assumption test aims to determine whether the data used is appropriate for multiple linear regression analysis based on the ordinary least square (OLS). In the classical assumption test, four tests must be fulfilled, namely:

A good regression model is to have a normal or near-normal data distribution (Ghozali, 2016). To test for normality, you can analyze the value of the Kolmogorov Smirnov Test. The basis for decision making is, if the probability value $>0.05$, then the regression model meets the normality assumption, then the regression model meets the normality assumption, and vice versa. 
VIF indicates which the other independent variables describe independent variables.

VIF value is greater than 10 , then multicollinearity occurs.

Autocorrelation occurs because consecutive observations over time are related to one another (Ghozali, 2016). To see the presence of autocorrelation, two autocorrelation tests are used, including the Durbin Watson and the Runs Tes.

Heteroscedasticity test aims to test whether there is an inequality of variants from the residuals or observation to other observations in the regression model. If the residual variance from one observation to another is fixed, it is called homoscedasticity, and if it is different, it is called heteroscedasticity. A good regression model is a homoscedasticity (Ghozali, 2016).

\section{Result}

The sampling of this study was carried out using a purposive sampling method. The sample selection was not random, but by using specific considerations and criteria determined by the researcher, mining companies listed on the Indonesia Stock Exchange (IDX) 2009-2019. The following are the criteria for selecting the research sample:

Table 3

Descriptive Statistics of Research Variables

\begin{tabular}{|c|c|c|c|c|}
\hline Variable & Minimum & Maximum & Mean & SD \\
\hline Stock Price (SP) & 515 & 54300 & 10122,12 & 13983,74 \\
\hline Earning Per Share (EPS) & 64,80 & 4361,08 & 1113,24 & 1200,1528 \\
\hline Net Profit Margin (NPM) & 3,97 & 30,48 & 15,2845 & 6,88191 \\
\hline Price to Book Value (PBV) & 0,36 & 9,51 & 2,0824 & 1,85993 \\
\hline Coal Price (HBA) & 53,51 & 112,67 & 84,6073 & 17,69961 \\
\hline
\end{tabular}

Source: Results of Multiple Linear Regression Data Processing, 2020

Based on Table 4.2 above, the following can be explained:

- The average share price (SP) is 10122.12 , the minimum value is 515 , the maximum value is 54300 , and the standard deviation is 13983.74 with the number of observations (n) of 33. The average value of the share price (SP) is close to the standard deviation value is 13409.173. Thus the deviation of the Share Price (SP) data is low.

- Average Earning Per Share (EPS) of 1113.24, a minimum value of 64.80, a 
maximum value of 4361.08, and standard deviation of 1200.1528 with total observations (n) of 33. Average Earning value Per Share (EPS) is close to the standard deviation of 1200.1528. Thus the deviation of Earning Per Share (EPS) data is low.

- The average Net Profit Margin (NPM) is 15.2845 , the minimum value is 3.97, the maximum value is 30.48 , and the standard deviation is 6.88191 with the number of observations (n) of 33. Net average value Profit Margin (NPM) is close to the standard deviation value of 6.88191. Thus the deviation of Net Profit Margin (NPM) data is low.

- The average Price to Book Value (PBV) is 2.0824, the minimum value is 0.36, the maximum value is 9.51 , and the standard deviation is 1.85993 with the number of observations (n) of 33. Average value The Price to Book Value (PBV) is close to the standard deviation value of 1.85993. Thus the deviation of the Price to Book Value (PBV) data is low.

- The average price of coal (HBA) is 84.6073 , the minimum value is 53.51, the maximum value is 112.67 , and the standard deviation is 17.69961 with the number of observations (n) of 33. Coal (HBA) is quite far from the standard deviation value of 17.69961. Thus the deviation of the Coal Price (HBA) data is relatively high.

The normality test results with the Kolmogorov Smirnov Test are as follows

Table 4

Normality Test Results with the Kolmogorov Smirnov Test

\begin{tabular}{|c|c|c|c|}
\hline Variable & Sig. & Critical Value & Information \\
\hline Residual & 0,168 & 0,05 & Normality \\
\hline
\end{tabular}

Source: Results of Multiple Linear Regression Data Processing, 2020

Based on the results of the normality test with the Kolmogorov Smirnov test above, it can be seen that the probability value $=0.168>0.05$, the regression model fulfils the normality assumption.

The results of the multicollinearity test using the VIF method are as follows:

Table 5

Multicollinearity Test Results with the VIF Method

\begin{tabular}{|c|c|c|c|}
\hline Equation & VIF & Critical Value & Information \\
\hline EPS & 2,225 & 10 & Not exposed to multicollinearity \\
\hline NPM & 2,255 & 10 & Not exposed to multicollinearity \\
\hline
\end{tabular}




\begin{tabular}{|c|c|c|c|}
\hline PBV & 1,382 & 10 & Not exposed to multicollinearity \\
\hline HBA & 1,429 & 10 & Not exposed to multicollinearity \\
\hline
\end{tabular}

Source: Results of Multiple Linear Regression Data Processing, 2020

Based on the multicollinearity test results with the VIF method, the VIF value is $<10$, meaning that all independent variables do not occur multicollinearity so that they do not bias the interpretation of the regression analysis results.

The detection of autocorrelation assumptions in this study was carried out using the Durbin-Watson test and the Runs Test.

1. The Durbin-Watson test

1). If the Durbin-Watson (D-W) value is below -2, it means that there is positive autocorrelation.

2). If the Durbin-Watson (D-W) value is between -2 to +2 , it means that there is no autocorrelation.

3). If the Durbin-Watson (D-W) value is above +2 , it means that there is negative autocorrelation.

From the regression results, the D-W statistic is 1.399 . Located between -2 to +2 . So Ho was accepted. This means that the estimated model does not have autocorrelation.

\section{Test Runs Test}

From the regression results obtained the Asymp value. Two-sided Sig / asymptotic significance of 1,000 , or a probability above $0.05(1,000>0.05)$. So Ho was accepted. This means that the estimated model does not have autocorrelation.

\section{Table 6}

Autocorrelation Test Results with the Runs Test Method

\begin{tabular}{|l|l|}
\hline \multicolumn{2}{|c|}{ Runs Test } \\
\hline & Unstandardized Residual \\
\hline Test Value $^{\mathrm{a}}$ & 124,21576 \\
\hline Cases < Test Value & 16 \\
\hline Cases >= Test Value & 17 \\
\hline Total Cases & 33 \\
\hline Number of Runs & 17 \\
\hline Z &, 000 \\
\hline Asymp. Sig. (2-tailed) & 1,000 \\
\hline
\end{tabular}

Source: Results of Multiple Linear Regression Data Processing, 2020 
The results of the heteroscedasticity test with Glejser are as follows:

Table 7

Heteroscedasticity Test Results with Glejser

\begin{tabular}{|c|c|c|c|}
\hline Variable & Sig. & Critical Value & Information \\
\hline EPS & 0,850 & 0,05 & Homoskedastisitas \\
\hline NPM & 0,897 & 0,05 & Homoskedastisitas \\
\hline PBV & 0,447 & 0,05 & Homoskedastisitas \\
\hline HBA & 0,724 & 0,05 & Homoskedastisitas \\
\hline
\end{tabular}

Source: Results of Multiple Linear Regression Data Processing, 2020

Based on the results of the heteroscedasticity test using Glejser, it can be seen that the probability value is $>0.05$. This means that the estimated model is free from heteroscedasticity.

The analysis in this research is the Multiple Linear Regression Analysis. This analysis is used to determine the effect of the variable Earning Per Share (EPS), Net Profit Margin (NPM), Price to Book Value (PBV), and Coal Price (HBA) on Stock Price (SP). Based on the results of calculations using the computer statistical program SPSS for Windows Version 25, the following results were obtained:

Table 8

Multiple Linear Regression Results

\begin{tabular}{|c|c|c|c|c|}
\hline Variable & $\begin{array}{c}\text { Regression } \\
\text { Coefficient }\end{array}$ & Standart Error & t-statistik & Sig. \\
\hline Constant & 1349,883 & 3303,355 & 0,409 & 0,686 \\
\hline EPS & 7,299 &, 612 & 11,921 & 0,000 \\
\hline NPM & $-269,436$ & 108,101 & 2,492 & 0,019 \\
\hline PBV & 4343,967 & 419,610 & 10,352 & 0,000 \\
\hline HBA & $-50,605$ & 44,848 & 1,128 & 0,269 \\
\hline $\mathbf{R}^{\mathbf{2}}$ & $: 0,937$ & & \\
\hline Adj. $\mathbf{R}^{\mathbf{2}}$ & $: 0,928$ & & \\
\hline F-statistik & $103,892 \mathrm{Sig}=0,000$. \\
\hline DW-statistik $: 1,399$ & $: 33$ \\
\hline $\mathbf{N}$ &
\end{tabular}

Source: Results of Multiple Linear Regression Data Processing, 2020 
Mathematically, the results of the multiple linear regression analysis can be written as follows:

$$
\mathrm{SP}=1349,883+7,299 \mathrm{EPS}-269,436 \mathrm{NPM}+4343,967 \mathrm{PBV}-50,605 \mathrm{HBA}
$$

The above equation shows the effect of independent $(\mathrm{X})$ on the dependent $(\mathrm{Y})$. The meaning of the regression coefficient is:

a. $b_{0}=1349,883$

This means that if Earning Per Share (EPS), Net Profit Margin (NPM), Price to Book Value (PBV), and Coal Price (HBA) are equal to zero, then the Share Price (SP) is 1349,883 .

b. $\mathrm{b} 1=7,299$

This means that if the increase in Earning Per Share (EPS) is 1 rupiah, then the Share Price (SP) will increase by 7,299 rupiahs, assuming other variables are constant (ceteris paribus).

c. $b 2=-269,436$

This means that if the increase in Net Profit Margin (NPM) is 1 per cent, then the Share Price (SP) will decrease by 269,436 rupiahs, assuming other variables are constant (ceteris paribus).

d. $b 3=4343,967$

This means that if the increase in Price to Book Value (PBV) is 1 per cent, then the Share Price (SP) will increase by 4343,967 rupiahs, assuming other variables are constant (ceteris paribus).

e. $b 4=-50,605$

This means that if the increase in the price of coal (HBA) is $1 \mathrm{U} \$$ / ton, the share price (SP) will decrease by 50.605 rupiahs, assuming other variables are constant (ceteris paribus).

\section{Table 9}

F Test Results

\begin{tabular}{|r|r|}
\hline F & Sig. \\
\hline & 103,892 \\
\hline
\end{tabular}

Source: Results of Multiple Linear Regression Data Processing, 2020

Based on the results of data processing, the Sig. F. $=0,000<$ Level of Significance $=$ 0.05 , then Ho is rejected, or Ha is accepted, meaning that it is concluded that simultaneously there is a significant effect on profitability (EPS and NPM), the ratio of market value (PBV) and HBA to Stock Price (SP). 
The t-test is used to prove the effect of Earning Per Share (EPS), Net Profit Margin (NPM), Return On Asset (ROA), Return On Equity (ROE), and Coal Price (HBA) on Stock Price (SP) individually ( $\mathrm{t}$-test) assuming that the other variables are constant or constant. Based on the results of calculations using the SPSS for Windows computer statistics program, the following results were obtained:

Table 10

T-test results

\begin{tabular}{|l|l|l|}
\hline \multicolumn{1}{|c|}{ Variable } & \multicolumn{1}{c|}{ t-statistik } & \multicolumn{1}{c|}{ Sig. } \\
\hline EPS & 11,921 & 0,000 \\
\hline NPM & 2,492 & 0,019 \\
\hline PBV & 10,352 & 0,000 \\
\hline HBA & 1,128 & 0,269 \\
\hline
\end{tabular}

Source: Results of Multiple Linear Regression Data Processing, 2020

1. Testing the Effect of Earning Per Share (EPS) on Stock Prices (SP)

Based on the results of data processing, the value of Sig.t $=0,000<$ Level of Significance $=0.05$, then $\mathrm{H} 1$ is accepted or $\mathrm{H} 0$ is rejected, meaning that it is concluded that there is a positive and significant effect of Earning Per Share (EPS) on Share Price (SP).

2. Testing the Effect of Net Profit Margin (NPM) on Stock Prices (SP)

Based on the results of data processing, the value of Sig.t $=0.019<$ Level of Significance $=0.05$, then $\mathrm{H} 2$ is accepted or $\mathrm{H} 0$ is rejected, meaning that there is a negative and significant effect of Net Profit Margin (NPM) on Share Price (SP).

3. Testing the Effect of Price to Book Value (PBV) on Stock Prices (SP)

Based on the results of the data processing, the value of Sig.t $=0,000<$ Level of Significance $=0.05$, then $\mathrm{H} 3$ is accepted or $\mathrm{H} 0$ is rejected, meaning that it is concluded that there is a positive and significant effect of Price to Book Value (PBV) on Share Prices (SP).

4. Testing the Effect of Coal Prices (HBA) on Stock Prices (SP)

Based on the results of data processing, the value of Sig.t $=0.269>$ Level of Significance $=0.05$, then $\mathrm{H} 4$ is rejected or $\mathrm{H} 0$ is accepted, meaning that it is concluded that there is a negative, but not significant, the effect of Coal Price (HBA) on Stock Price (SP). 
The results of the regression with the OLS (Ordinary Least Square) method obtained Adjusted R2 (Coefficient of Determination) of 0.928, meaning that the dependent variable (Y) in the model, namely Stock Price (SP) is explained by independent variables, namely Earning Per Share (EPS), Net Profit Margin. (NPM), Price to Book Value (PBV), and Coal Price (HBA) of 92.8\%, while other factors outside the model explain the remaining $7.2 \%$.

\section{Conclusion}

The ratio of earning per share (EPS) partially has a significant positive effect on stock prices. This means if EPS has increased, then the stock price will also experience a significant increase. The small value of EPS is due to the increase in share prices and a large number of shares outstanding, which exceeds the increase in net income. The effect of EPS on the share price is $65.4 \%$. Nailufarh's research results (2016); Nurriqli \& Sany (2018) stated that EPS has a positive and significant effect on stock prices.

The ratio of net profit margin (NPM) partially has a significant negative effect on stock prices. This means, if the NPM has increased, then the share price will experience a significant decrease. The effect of NPM on stock prices is $0.2 \%$. This result is different from the research of Nailufarh (2016), Nurriqli \& Sany (2018), Simorangkir (2019) states that NPM has a significant positive effect on stock prices. This difference is caused by technical factors, the period of observation, and the issuer chose. In this study, the observation period used was 11 years, and the issuers selected were ADRO, ITMG, and PTBA.

The price to book value (PBV) ratio partially has a significant effect on stock prices. This means, if the PBV has increased, then the stock price will also experience a significant increase. This is because PBV is the result of comparing the market share price with the issuer's book value. The effect of PBV on stock prices is $60.9 \%$. The results of research by Hing, Alamsyah \& Pradiani (2020); Gautama \& Aisah (2014) stated that price to book value (PBV) has a significant effect on mining stock prices.

The reference coal price (HBA) partially has a negative but insignificant effect on stock prices. This means, if the coal price has increased, the share price will experience an insignificant decrease. The effect of HBA on stock prices is $5.5 \%$. This result is different from Luthfiyah's research (2020) which states that HBA has a positive and significant effect on stock prices. This difference is caused by the period of observation and the issuer selected. However, according to Wijen (in Pandu, 2020), the decline in HBA is only temporary, so it 
cannot be said to be a negative sentiment.

Simultaneously, the ratio of Earning Per Share (EPS), Net Profit Margin (NPM), Price to Book Value (PBV), and Coal Price (HBA) has a significant effect on stock prices. Sig explains this. F. $=0,000<$ Level of Significant $=0.05$ and the value of Adjusted R2 is 0.928 , which means that the dependent variable (Y) in the model, namely Stock Price (SP), is explained by an independent variable of $92.8 \%$, while other factors explain the remaining $7.2 \%$ outside of the model.

\section{REFERENCES}

Arikunto, Suharsimi. 2017. Prosedur Penelitian Suatu Praktek. Jakarta: Rineka Cipta. Mamduh, M. Hanafi. 2010. Manajemen Keuangan. Yogyakarta: BPFE.

Agus Sartono. 2010. Manajemen Keuangan Teori dan Aplikasi. Edisi 4. Yogyakarta: BPFE.

Ghozali, Imam. 2016. Aplikasi Analisis Multivariat dengan Program SPSS. Semarang: Badan Penerbit Universitas Diponegoro.

Gujarati, Damodar \& Dawn C. Porter. 2012. Basic Econometrics. New York: Mc Graw Hill Inc.

Sutrisno, 2014. Manajemen Keuangan Teori, Konsep dan Aplikasi. Yogyakarta: Ekonisia. Nasir, A., Ideputri, M.E., Muhith, A.,. 2011. Konsep Pembuatan Karya Tulis dan Tesis untuk Mahasiswa Kesehatan. Yogyakarta: Nuha Medika.

Harmono. 2014. Manajemen Keuangan Berbasis balanced scored. Jakarta: PT Bumi Aksara Santoso, Singgih. 2018. Metode Penelitian. Jakarta: Elek Media Komputindo.

Hartono, Jogiyanto. 2012. Teori Portofolio dan Analisis Investasi Yogyakarta: BPFE. Sugiyono. 2017. Metode Penelitian Bisnis. Bandung: Alfabeta.

Husnan, Suad. 2011. Pembelanjaan Perusahaan (Dasar-dasar Manajemen Keuangan). Yogyakarta: Liberty.

Samsul, Muhammad. 2016. Pasar Modal \& Manajemen Portofolio. Edisi Kedua. Jakarta: Erlangga.

Alexandri, Moh. Benny. 2009. Manajemen Keuangan Bisnis: Teori dan Soal. Bandung: Penerbit Alfabeta.

Azis, Musdalifah, dkk. 2015. Manajemen Investasi: Fundamental, Teknikal, Perilaku Investor dan Return Saham. Yogyakarta: Deepublish.

Darmadji, Tjiptono dan Fakhruddin. 2012. Pasar Modal di Indonesia. Edisi Ketiga. Jakarta: Salemba Empat

Wiagustini. 2014. Manajemen Keuangan. Bali. Udayana University Press.

Kasmir. 2019. Analisis Laporan Keuangan. Depok: Rajawali Pers Hery. 2016. Analisis Laporan Keuangan. Jakarta: Grasindo.

Setyawan, Aditya. (2014). Menyusun Tinjauan Teori, Kerangka Teori dan Kerangka Konsep Penelitian. Surakarta: Politeknik Kesehatan Kemenkes.

Fahmi, Irham. 2018. Pengantar Manajemen Keuangan. Bandung: Alfabeta Martono. 2010. Bank dan Lembaga Keuangan. Yogyakarta: Ekonisia

Keown, Arthur J., Martin, John D., Petty, J. William, Scott, David F. JR. 2011. Manajemen Keuangan: Prinsip dan Penerapan. Jakarta: PT Indeks.

Najib, M. Akmal 2017. Pengaruh Harga Batubara, Earning Per Share dan Return On Assets Terhadap Harga Saham Perusahaan Pertambangan Batubara yang Terdaftar di Bursa Efek Indonesia. Skripsi. Fakultas Ekonomi dan Bisnis Universitas Brawijaya.

Hernitra, Wellarizma 2011. Pengaruh Pengungkapan Corporate Social Responsibility Terhadap Profitabilitas Perusahaan. Skripsi. Fakultas Ekonomi Universitas Jember 
Kesuma, Ali 2010. Analisis Faktor Yang Mempengaruhi Struktur modal serta Pengaruhnya terhadap Harga Saham Perusahaan Real Estate yang Go Public di Bursa Efek Indonesia. Manajemen dan Kewirausahaan, volume 11(1):38-45

Rinowigunanto, Rosy. 2017. Pengaruh Harga Batubara dan Minyak Dunia Terhadap Return Saham Sektor Pertambangan yang Terdaftar di Bursa Efek Indonesia Periode 2011-2015. Skripsi. Fakultas Ekonomi dan Bisnis. Universitas Katholik Soegijapranata.

Wulandari, Anggi Ayu. 2014. Pengaruh Earning Per Share (EPS) Dan Price To Book Value (PBV) Terhadap Harga Saham (Studi Kasus Pada Sektor Pertambangan Batubara yang Terdaftar di BEI periode 2009 - 2012). Skripsi. Fakultas Ekonomi. Universitas Komputer Indonesia.

Agustina, Lia. 2018. Pengaruh EPS, CR, DER, dan ROA Terhadap Harga Saham Perusahaan Batu Bara yang Terdaftar di Bursa Efek Indonesia Periode 2013-2015. Skripsi. Fakultas Ekonomi dan Bisnis. Universitas Muhammadiyah Surakarta.

Luthfiyah. 2020. Pengaruh EPS, Harga Batubara Acuan dan Nilai Tukar Terhadap Harga Saham (Studi Pada Perusahaan Subsektor Pertambangan Batubara yang Terdaftar di Bei Periode 2014-2018). Skripsi. Fakultas Ekonomi dan Bisnis. Universitas Pertamina.

Natarsyah, 2010, Analisis Pengaruh Beberapa Faktor Fundamental dan Resiko Sistematik Terhadap Harga Saham : Kasus Industri Barang Konsumsi yang Go Public di Pasar Modal Indonesia. Jurnal Ekonomi dan Bisnis Indonesia. Vol.

15.(3):294-312.

Sudiyatno, Bambang. 2010. Peran Kinerja Keuangan Dalam Menentukan Faktor Fundamental Makroekonomi, Risiko Sistematis, Kebijakan Perusahaan terhadap Nilai Perusahaan. Disertasi. Doktor Ilmu Ekonomi Universitas Dipenogoro Semarang.

Djazuli, Ahamd \& Fitri R. Aisjah. 2016. Pengaruh Laba Akuntansi, Nilai Buku Ekuitas, dan Total Arus Kas terhadap Harga Saham (Studi pada Perusahaan Manufaktur yang Terdaftar di Bursa Efek Indonesia). Jurnal Aplikasi Manajemen. Vol.14(1):169-175.

Anita Munir. 2020, Analysis of PT Aneka Tambang tbk During Covid Pandemic 19, Journal of management and Leadership. Vol.3(2): 19-25.

Ansor, 2010, Analisis Pengaruh, ROA, PBV, EPS, PER, Kurs dan Suku Bunga terhadap Return Saham (Kajian Empiris pada Perusahaan Manufaktur yang Terdaftar di BEI Tahun 2006-2008), Tesis, Program Pasca Sarjana Magister Manajemen Universitas Diponegoro, Semarang.

Margaretha, Farah \& Karnida Retta Ginting. 2016. Faktor-faktor yang Mempengaruhi Struktur Modal pada Perusahaan Manufaktur yang Terdaftar di Bursa Efek Indonesia. Jurnal Ekonomi. Vol.7(1):55-67.

Nailufarh, Qurratul A'yun. 2016. Debt to Asset Ratio, Net Profit Margin, Earning Per Share, Deviden Per Share, Book Value Per Share, Return On Invesment terhadap Harga Saham Perusahaan Tambang Batu Bara pada Bursa Efek Indonesia. Journal of Research in Economics and Management. Vol.15(2):330-332.

Nurriqli, Arifia \& Sany Sofyan. 2018. Pengaruh Faktor-faktor Fundamental terhadap Harga Saham (Studi pada Perusahaan Sub Sektor Pertambangan Batubara yang Terdaftar di Bursa Efek Indonesia Periode 2012-2015). Kindai. Vol.14(1):1-11.

Aspara, R. Hadi. \& Astiwi Indriani. 2017. Analisis Pengaruh Crude Oil Price, Earning Per Share, Price To Book Value, Return On Assets dan Debt To Equity Ratio Terhadap Harga Saham Perusahaan Batubara yang Terdaftar di Bursa Efek Indonesia Periode 2012-2016. Diponegoro Journal of Management. Vol. 6(4):1-13.

Pebrianti, Yulia. 2018. Pengaruh Operating Expenses dan Sales Terhadap Net Profit Margin (NPM) Pada Perusahaan Sektor Pariwisata Bursa Efek Indonesia Periode 20122016. I-FINANCE Vol.04 No.02 Desember 2018:196-205

Simorangkir, Rona Tumiur Mauli Carolin. 2019. Pengaruh Kinerja Keuangan terhadap Return 
Saham Perusahaan Pertambangan. Jurnal Bisnis dan Akuntansi. Vol.21(2):155-164.

Anbiya, Resti Al \& Saryadi. 2018. Pengaruh ROE, EPS, CR dan DER Terhadap Harga Saham Pada Perusahaan Subsektor Pertambangan Batubara yang Terdaftar di Bursa Efek Indonesia Tahun 2013-2016. Jurnal Fakultas Ilmu Sosial dan Ilmu Politik. Universitas Diponegoro.

Investasi.kontan.co.id. (2020, 5 Mei). Kinerja 4 emiten batubara ini: PTBA, ADRO, DOID \& ITMG kompak tergerus di 2019. Diakses pada 1 Oktober 2020, dari https://investasi.kontan.co.id/news/kinerja-4-emiten-batubara-ini-ptba-adro-doid-itmgkompaktergerus-di-2019?page $=$ all

Kumparan.com (2020, 1 April). 5 Perusahaan Tambang yang Aman untuk Investasi Pilihan Analis. Diakses pada 1 Oktober 2020, dari https://kumparan.com /kumparanbisnis/5-perusahaan-tambang-yang-amanuntuk-investasipilihan-analis

Market.bisnis.com. (2020, 7 Januari). HBA Batu Bara Turun, Indeks Saham Tambang Justru Menghijau. Diakses pada 1 Oktober 2020 dari https://market.bisnis.com /read/20200107/189/1187824/hba-batu-bara-turun-indeks-saham-tambang justrumenghijau

Tradingview.com (2020, 22 Desember). Nilai Kapitalisasi Pasar Sektor Energi dan Mineral. Diakses pada 22 Desember 2020, dari https://id.tradingview.com /markets/stocks-indonesia/sectorandindustry-sector/energy-minerals/industries/

Rti.co.id (2020, 22 Desember). Nilai Kapitalisasi IHSG 22 Desember 2020. Diakses pada 22 Desember 2020, dari https://analytics2.rti.co.id/?m_id=1\&sub_m=s6

Adaro.com (2019, 31 Desember). Laporan Keuangan Tahun 2009 - 2019. Diakses pada 1 September 2020, dari http://www.adaro.com/pages/read /10/42/Annual $\% 20$ Report

PTBA.co.id (2019, 31 Desember). Laporan Keuangan Tahun 2009 - 2019. Diakses pada 1 September 2020, dari http://www.ptba.co.id/en/company-report/annual-report

ITMG.co.id (2019, 31 Desember). Laporan Keuangan Tahun 2009 - 2019. Diakses pada 1 September 2020, dari https://itmg.co.id/id/investor-relation/annual-report

Minerba.esdm.go.id (2019, 31 Desember). Harga Batu Bara Acuan Tahun 2009 2019. Diakses pada 1 September 2020, dari https://www.minerba.esdm.go.id /harga_acuan

Finance.yahoo.com (2019, 31 Desember). Jakarta Composite Index; Daily Stock Price of PTBA, ADRO and ITMG. Diakses pada 1 September 2020, dari https://finance.yahoo.com/quote/\%5EJKSE?p=\%5EJKSE

Yefadvisor.com (2019, 4 Oktober). Teori Dow, Memahami Konsep Arah Pergerakan Pasar. Diakses pada 1 Desember 2020, dari https://yefadvisor.com/teori-dow/

Medcom.id (2020, 27 Agustus) Usia Cadangan Batu Bara RI Tahan Hingga 62 Tahun.

Diakses pada 15 Februari 2021, dari https://www.medcom.id/ekonomi/bisnis

/MkMG27DN-usia-cadangan-batu-bara-ri-tahan-hingga-62-tahun

BPS.go.id (2020, 16 September) Laporan Perekonomian Indonesia 2020. Diakses pada 15 Februari 2021, dari https://www.bps.go.id/publication/2020/09/16

/be7568ad496829f35cea4b27/laporan-perekonomian-indonesia-2020.html 